\title{
A comparative analysis of handling level of lifelong learning competences in social education curricula, Turkey and Ireland sample ${ }^{1}$
}

\author{
E. Seda Koç ${ }^{2}$ \\ Aliye Erdem ${ }^{3}$
}

\begin{abstract}
Developing and ever-changing information technology brings together many innovations by renewing the human profile societies need in a significant way. "Lifelong Learning Understanding" which is one of the most important of these innovations, makes it necessary to change the basic competences and skills stand in the curricula. Accordingly, the education curricula are expected to provide lifelong learning understanding. In this study it was aimed to analyze the handling level of the lifelong learning competences in the social education curricula of Turkey and Ireland comparatively. Eight key competences, recommended EU member countries to conduct their educational policies within the context of lifelong learning by the European Union (EU), was used as references in the analysis of the curricula. It has been tried to determine whether lifelong learning competences are included in the curricula or not and which competences have been mentioned the most and which has been mentioned the least. Data required was collected in accordance with "document analysis" method, which is one of the qualitative research methods, and utilized from "content analysis" technique for the analysis of the collected data. According to the findings of the study it was found that the most frequent competences were mathematical competence and basic competences in science and technology in TSCC. It was also seen that the competences of communication in the mother tongue, social and civic competences, the learning to learn competence, and mathematical competence and basic competences in science are of leading importance in SPHE. Absence of the communication in foreign languages competence in TSSC can be said as the most prominent difference between the ISSC and TSSC.
\end{abstract}

Keywords: Lifelong Learning, Lifelong Learning Competences, Social Education Curricula

\section{Introduction}

Continuously changing and developing information technologies have a notable effect on the human profile required by society, and the greatest reflection of these changes can be observed in education processes. In this regard, the priority skills to be transferred to individuals in the education process are "lifelong learning skills".

\footnotetext{
${ }^{1}$ This article was submitted at 1 st International Conference on Lifelong Education and Leadership for All-ICLEL 2015 2 Assistant Professor, Kastamonu University, Faculty of Education, Department of Educational Science, eskoc@kastamonu.edu.tr

3 Assistant Professor, Ankara University, Faculty of Educational Sciences, Department of Elemantry Education,; aliye.erdem@ankara.edu.tr
} 
Koç, E. S., \& Erdem, A. (2016). A comparative analysis of handling level of lifelong learning competences in social education curricula, Turkey and Ireland sample. International Journal of Human Sciences, 13(1), 1293-1303. doi:10.14687/ijhs.v13i1.3618

The concept of lifelong learning is defined by Kulich as a person's spreading education to all of his life, and by White as individuals' preparation to be able to direct their lives (as cited in Karakuş, 2003).A review of other definitions of the same concept reveals a definition ensuring secondary opportunities for individuals by means of developing basic skills and provision of upper level learning opportunities (Soran, Akkoyunlu, Kavak, 2006). As to the definition of the Ministry of National Education, lifelong learning is defined as "all types of activities that individuals take part in throughout their lives aimed at developing their knowledge, skills, interests and competences related to personal, societal, social and employment approaches" (MEB, 2009). In the light of all these definitions, the concept of lifelong learning may be defined as "all types of learning opportunities that provide the individual with the opportunity to acquire learning habits and skills by means of formal or informal processes, within or outside school".

Whereas the definitions about the concept of lifelong learning change with regard to person, time and environment, some definitions agree with each other in some common points. These are;

$\checkmark$ It can be summarized as starting in the pre-school period, learning continues after retirement,

$\checkmark$ It includes official and unofficial education process,

$\checkmark$ It is a requirement for the information society of the future,

$\checkmark$ It is required so as to keep up with social changes,

$\checkmark$ Regardless of age, gender or social position; everyone benefit from the universal rights of learning,

$\checkmark$ Importance of learning outside education-teaching institutions should be accepted popularly,

$\checkmark$ Development of skills for finding information, developing a found information and using it independently and actively,

$\checkmark$ Motivating an individual to learn independently, on his own

$\checkmark$ Providing unlimited learning or gaining information throughout life (As cited in Ersoy, 2009).

Being a concept of which origin is extended to the ideas of Czech teacher Comenius, lifelong learning has begun to gain its popularity in last 25 years. The primary factor among the ones, accelerating this popularity, is that the concept is used not only by teachers, but also by researches from different disciplines; such as economists and sociologists and that they began intending to cut "the fabric" in accordance with their own forms (Beycioğlu, 2008).

Lifelong learning is a concept that is often emphasised by many organisations and institutions in the development of education policies, whether national or international. In studies conducted since the 1990 s, especially by the European Union Commission, the lifelong learning concept has been accepted as a fundamental policy in the development of active citizenship, social cohesion and employment, and has become an important component of the European Union Employment Strategy (Göksan, Uzundurukan, Keskin, 2009). The 10-Year Plan accepted by the European Union Member States in 2000 includes items related to lifelong learning, while the Commission included eight key competences in the 2006 report entitled "The Key Competences for Lifelong Learning - A European Framework". These are: communication in the mother tongue, communication in foreign languages, mathematical competence and basic competences in science and technology, digital competence, learning to learn, social and civic competences, sense of initiative and entrepreneurship, and cultural awareness and expression.

The key competences are all considered equally important, because each of them can contribute to a successful life in a knowledge society. Many of the competences overlap and interlock: aspects essential to one domain will support competence in another. Competence in the fundamental basic skills of language, literacy, numeracy and in information and communication 
Koç, E. S., \& Erdem, A. (2016). A comparative analysis of handling level of lifelong learning competences in social education curricula, Turkey and Ireland sample. International Journal of Human Sciences, 13(1), 1293-1303. doi:10.14687/ijhs.v13i1.3618

technologies (ICT) is an essential foundation for learning, and learning to learn supports all learning activities. There are a number of themes that are applied throughout the Reference Framework: critical thinking, creativity, initiative, problem solving, risk assessment, decision taking, and constructive management of feelings play a role in all eight key competences. (EU,2006)

The curriculum implemented in schools is important for the education of individuals in line with the competences outlined by the Commission, and in this sense, should be developed in accordance with the lifelong learning approach. In order for the attitude and related skills of lifelong learning to be instilled in students from an early age, the curriculum to be developed according to the approach should be practiced effectively from the very beginning of the teachinglearning process. In this regard, it is expected that the skills covered especially in the primary education curriculum will be congruent with the lifelong learning approach. The curriculum of Social Studies lesson is among the aforesaid programs, which are expected to be developed in convenience with the idea of lifelong learning.

Social studies lesson is one of the most fundamental lessons for students to receive information about society and its problems, to learn their responsibilities as a good citizen, to understand human relations, to comprehend national and universal properties and values. For this reason, it is a necessity that the curriculum of social studies lesson, which has an indisputable position for an individual's character development to be productive, efficient and in harmony with society, has to be constantly developed by considering scientific and technological developments, social cultural changes, social, political and economic evolutions and needs of an individual and society (Aykaç, 2007). Alongside with all of these mentioned features, it is also expected that qualifications of lifelong learning, which are aimed to be commonly gained by individuals from different countries as the result of the view of globalizing education, must reverberate in the curriculum. It is observed that defining lifelong learning to be a skill, among the fundamentals of the new elementary curriculum of the Turkish Education System and that the skill must be acquired by the students as it is similar to the EU's projects related to education (Sağlam, Özüdoğru and Çıray, 2011).

This study makes a comparative examination of the $4^{\text {th }}$ - and $5^{\text {th }}$-grade social studies primary education curricula of Turkey and Ireland to ascertain the extent to which lifelong learning competences and related skills are included. The study also aims to identify the presence or absence of the emphasised competences in the curriculum. The findings of the study can serve as operational feedback, facilitating the education curriculum in becoming consistent with the approach of lifelong learning and the development processes of the curriculum.

\section{Method}

\subsection{Model of the Study}

This study was conducted according to the case study model, as a form of qualitative research. The case study adopts an empirical research technique that is used in cases where multiple evidence exists from more than one data source, where a case is undertaken within its own environment, and where the boundaries between the phenomenon and content are not definitive (Yin, 1984 quoted from Yildırım \& Şimşek, 2008). For the purpose of the study, the curriculum of each country is considered as a separate case, after a comparison is made of the curricula to identify lifelong learning competences and the findings were presented by the researchers. 
Koç, E. S., \& Erdem, A. (2016). A comparative analysis of handling level of lifelong learning competences in social education curricula, Turkey and Ireland sample. International Journal of Human Sciences, 13(1), 1293-1303. doi:10.14687/ijhs.v13i1.3618

\subsection{Data Sources}

The data sources for the study are the $4^{\text {th }}$ - and $5^{\text {th }}$-grade social study curricula for primary education in Turkey and Ireland. The objectives, skills and attainments of the curricula were comparatively examined, with emphasis on the key competences outlined by the European Commission. As there is no specific Social Studies subject in Ireland, the data source was selected as the subject syllabus related to history, geography and social and personal health education. As the titles of the curricula will be mentioned frequently in the study, the abbreviation TSSC will be used to denote the Turkish social studies curriculum, while ISSC will refer to the Irish social studies curriculum.

\subsection{Data Collection and Analysis Process}

The data used in the study was obtained by means of a "document analysis", involving an analysis of written materials containing facts and knowledge about facts, and including such procedures as accessing the documents, checking the originality of the obtained texts, comprehending the documents, analysing the data, and using the results (Yıldırım \& Şimşek, 2008). The analysis of the obtained data was carried out using a content analysis technique, as an interpretive technique that is generally used to ascertain the common points in numerous texts, allowing generalisations to be made, aimed at constructing and categorising the most significant aspects, moving from qualitative to quantitative findings (Gökçe, 2006).

\section{Results}

\section{Lifelong Learning Competences in the TSSC}

Subject area skills and attainments were examined with a view to determining whether or not lifelong learning competences were included in the TSSC. Accordingly, it was found that 15 main skills were included in the curriculum, representing a majority of the competences and related skills outlined by the European Commission. Primary focus was found to be on mathematical competence and basic competences in science and technology and communication in the mother tongue. In contrast, it was found that the competences of communication in foreign languages and cultural awareness and expression were not included in the curriculum, along with adequate social and civic competences. In this light, it was concluded that the curriculum aimed to develop the social participation skills of the students, but that the global citizenship skills encompassing different countries, especially in Europe, in the scope of civic competence was not included.

In addition to general skills, the skills expected to be attained by students in each unit based on the grade was presented in the curriculum. A review of these showed that skills such as critical thinking, decision making and problem solving, as requirements of mathematical competency, as well as basic competences in science and technology, communication in the mother tongue, and learning to learn, were all found to be included in the curriculum.

Lastly each of the examples of activities and explanations related to the attainments of the TSSC were reviewed separately, taking into account the grade level. The key competences with the number of regarding attainments of TSSC are presented in table1. 
Koç, E. S., \& Erdem, A. (2016). A comparative analysis of handling level of lifelong learning competences in social education curricula, Turkey and Ireland sample. International Journal of Human Sciences, 13(1), 1293-1303. doi:10.14687/ijhs.v13i1.3618

Table1. Key competences with the number of regarding attainments of TSSC

\begin{tabular}{|l|l|l|}
\hline & $\begin{array}{c}\text { Number of Regarding } \\
\text { Attainments }\end{array}$ \\
\hline \multicolumn{1}{|c|}{ Key Competences } & 4th Level & th Level \\
\hline Communication in the mother tongue & 3 & 5 \\
\hline Communication in foreign languages & & \\
\hline $\begin{array}{l}\text { Mathematical competence and basic } \\
\text { competences in science and technology }\end{array}$ & 16 & 14 \\
\hline Digital competence & 10 & \\
\hline Learning to learn & 6 & 10 \\
\hline Social and civic competences & 10 & 7 \\
\hline Sense of initiative and entrepreneurship & 3 & 2 \\
\hline Cultural awareness and expression & 8 & 8 \\
\hline
\end{tabular}

As it can be seen in table 1, 46 attainments are presented at the $4^{\text {th }}$ grade, among which 16 are related to mathematical competence and basic competences in science and technology, 10 are related to social and civic competences, eight are related to the cultural awareness and expression, six are related to learning to learn competences, three are related to initiative and entrepreneurship and three are related to communication in the mother tongue. A further 46 attainments are included in the $5^{\text {th }}$ grade of the TSSC, with 14 are related to mathematical competences and basic competences in science and technology, 10 are related to learning to learn competences, eight are related to cultural awareness and expression competences, seven are related to social and civic competences, five to communication in the mother tongue competences and two to initiative and entrepreneurship competences. The skills related to cultural awareness and expression which are not included among the skills of the curriculum can be found in the $4^{\text {th }}$ grade and $5^{\text {th }}$ grade attainments; however, the lack of the communication in foreign languages competence is apparent at both grade levels. Furthermore, skills related to digital competence are included within the general skills, but are not given directly by means of attainments, and students are required to use the Internet in some of the given activity examples. For example:

"Virtual Field Visit" (Virtual visits by means of the Internet)

"Researching on the Internet" (Researching the features of cities where international sporting events took place) (MEB, 2006).

\section{Lifelong Learning Competences in the ISSC}

As there is no such subject as Social Studies in Ireland, the curricula of the history, geography and social, personal and health education subjects were reviewed. Curricula with similar content were analysed to identify the key competences, and the aims, broad objectives and skills and objectives at each grade level were considered. Findings related to the history curriculum, in this regard, are given below.

The review of the 11 aims of the history curriculum, undertaken to identify the key competences, showed that there were four aims each for the social and civic competences and learning to learn competences, two related to cultural awareness and expression competences, and one related to mathematical competence and basic competences in science and technology. Of the 13 broad objectives identified in the curriculum, five are related to social and civic competences, three are related to learning to learn competences and mathematical competence and basic competences in science and technology, while cultural awareness and expression competences both have two related objectives each. 
Koç, E. S., \& Erdem, A. (2016). A comparative analysis of handling level of lifelong learning competences in social education curricula, Turkey and Ireland sample. International Journal of Human Sciences, 13(1), 1293-1303. doi:10.14687/ijhs.v13i1.3618

The target of "communicating historical understanding in a variety of ways, using appropriate language and other techniques or media" (Ireland Primary School Curriculum, 1999) under the broad objective is evaluated as being related to both the digital and communication in foreign languages competences. Another finding that is of interest in relation to the curriculum is that not only Ireland, but also other countries around the world, though especially in Europe, are taken into consideration with regard to the goals related to the cultural awareness and expression competences. For example, "develop a sense of personal, local, national, European and wider identities through studying the history and cultural inheritance of local and other communities" (Ireland Primary School Curriculum, 1999)

When the curriculum was reviewed taking into account the grade level, it was seen that there were six skills and explanations related to these skills, concerning time and chronology, change and continuity, the use of evidence, working as a historian, synthesis and communication, and empathy. These and other skills related to the communication in the mother tongue competence and the competences of social and civic, learning to learn, mathematical competence and basic competences in science and technology and sense of initiative and entrepreneurship competences are also included in the curriculum, as the need arises.

The curricula included 49 objectives for $4^{\text {th }}$-grade students and 55 for those at the $5^{\text {th }}$ grade. They are listed in table 2 below.

Table2. Key competences with the number of regarding objectives of history curriculum of Ireland

\begin{tabular}{|l|l|l|}
\hline & \multicolumn{2}{c|}{$\begin{array}{c}\text { Number of Regarding } \\
\text { Objectives }\end{array}$} \\
\hline \multicolumn{1}{|c|}{ Key Competences } & 4 th Level & 5 th Level \\
\hline Communication in the mother tongue & 12 & 9 \\
\hline Communication in foreign languages & & \\
\hline $\begin{array}{l}\text { Mathematical competence and basic } \\
\text { competences in science and technology }\end{array}$ & 2 & 5 \\
\hline Digital competence & 8 & 8 \\
\hline Learning to learn & 10 & 9 \\
\hline Social and civic competences & & \\
\hline Sense of initiative and entrepreneurship & 9 & 12 \\
\hline Cultural awareness and expression & 8 & 12 \\
\hline
\end{tabular}

As shown in table 2 for the $4^{\text {th }}$ grade, it was found that there were 12 objectives related to communication in the mother tongue, 10 related to learning to learn, nine related to the sense of initiative and entrepreneurship, eight each for digital competence and the cultural awareness and expression competences and two related to mathematical competence and basic competences in science and technology. At the $5^{\text {th }}$-grade level, it was seen that there are 12 objectives related to the sense of initiative and entrepreneurship, and the cultural awareness and expression competences, nine each for the learning to learn and communication in mother tongue competences, eight related to digital competence and five related to mathematical competence and basic competences in science and technology. In regards to communication in foreign languages and social and civic competences, no common objectives were identified at either grade level.

Regarding the geography subject curriculum, there are seven aims that are connected to all of the competences, aside from the communication in foreign languages competence. A review of the broad objectives of the curriculum revealed 15 objevtives related to the common competences.

The majority of objectives are related to the learning to learn and mathematical competence and basic competences in science and technology, and the students are expected to learn skills such as critical thinking, creativity and entrepreneurship by means of these objectives. For example, 
Koç, E. S., \& Erdem, A. (2016). A comparative analysis of handling level of lifelong learning competences in social education curricula, Turkey and Ireland sample. International Journal of Human Sciences, 13(1), 1293-1303. doi:10.14687/ijhs.v13i1.3618

$\checkmark$ study the impact of environmental conditions on the lives of people in the locality and in other areas, and come to appreciate some of the ways in which humans use, modify or influence their environments,

$\checkmark$ use and value creative, innovative thinking in the exploration and/or resolution of

buman and environmental issues (Ireland Primary School Curriculum, 1999)

In a review of the skills and objectives of the curriculum conducted according to grade level, it was found that there are 10 common skills for the $4^{\text {th }}$ and $5^{\text {th }}$ grades. These skills can be listed as,

1. A sense of place,

2. A sense of space,

3. Using pictures, maps and globes,

4. Questioning

5. Observing

6. Predicting

7. Investigating and experimenting

8. Estimating and measuring

9. Analysing

10. Recording and communicating (Ireland Primary School Curriculum,1999)

A review of given skills in terms of key competences found that the competences and skills emphasised were learning to learn, cultural awareness and expression, and mathematical competence and basic competences in science and technology. There were no findings of skills related to competences of communication in foreign languages and social and civic competences, while other key competences were undertaken as appropriate. The review of objectives revealed 65 objectives for the $4^{\text {th }}$ grade and 85 objectives for the $5^{\text {th }}$ grade. They are presented in table 3 below.

Table3. Key competences with the number of regarding objectives of geopraphy curriculum of Ireland

\begin{tabular}{|c|c|c|}
\hline & \multicolumn{2}{|c|}{$\begin{array}{c}\text { Number of Regarding } \\
\text { Objectives }\end{array}$} \\
\hline Key Competences & 4th Level & 5th Level \\
\hline Communication in the mother tongue & 9 & 9 \\
\hline Communication in foreign languages & & \\
\hline $\begin{array}{l}\text { Mathematical competence and basic } \\
\text { competences in science and technology }\end{array}$ & 27 & 37 \\
\hline Digital competence & 1 & 5 \\
\hline Learning to learn & 4 & 10 \\
\hline Social and civic competences & 10 & 11 \\
\hline Sense of initiative and entrepreneurship & 12 & 12 \\
\hline Cultural awareness and expression & 2 & 1 \\
\hline
\end{tabular}

As seen from table 3 , the majority of objectives for both grade levels $\left(4^{\text {th }}\right.$ grade $=27 / 5^{\text {th }}$ grade $=37$ ) were related to mathematical competence and basic competences in science and technology. Although social and civic competences were not included within the scope of the skills, the competences that were lacking were aimed to be undertaken by means of the aims and concerning these competences 10 objectives at the $4^{\text {th }}$ grade level and 11 at the $5^{\text {th }}$ grade were included. Regarding the learning to learn competences, it was seen that there was an insufficient number of objectives for the $4^{\text {th }}$ grade $(\mathrm{f}=4)$, whereas there were 10 goal related to this competence for the $5^{\text {th }}$-grade level. No common competence of communication in foreign languages for both grade levels was found, and the number of objectives related to digital competence $(f=1 / 5)$ and the cultural awareness and expression competences $(\mathrm{f}=2 / 1)$ were not of a sufficient number. 
Koç, E. S., \& Erdem, A. (2016). A comparative analysis of handling level of lifelong learning competences in social education curricula, Turkey and Ireland sample. International Journal of Human Sciences, 13(1), 1293-1303. doi:10.14687/ijhs.v13i1.3618

The final curriculum reviewed within the scope of the ISSC was the social, personal, health and education (SPHE) subject of the curriculum. The curriculum of this subject comprises six aims and 15 broad objectives, and the curriculum goals were found to be associated with social and civic competence, the sense of initiative and entrepreneurship, and the cultural awareness and expression competences. A review of the broad objectives showed that, in addition to these competences, goals concerning mathematical competence and basic competences in science and technology are undertaken by means of the broad objectives.

As was the case in the other two curricula, it was seen that skills were not included in the SPHE, and therefore it was the objectives that were subjected to review.

The curriculum comprises 100 objectives for the $4^{\text {th }}$ grade and 102 objectives for the $5^{\text {th }}$ grade as it is shown in table 4 below.

Table4. Key competences with the number of regarding objectives of SPHE

\begin{tabular}{|l|l|l|}
\hline \multicolumn{1}{|c|}{ Key Competences } & \multicolumn{2}{c|}{$\begin{array}{c}\text { Number of Regarding } \\
\text { Objectives }\end{array}$} \\
\hline Communication in the mother tongue & 4 th Level & 5 th Level \\
\hline Communication in foreign languages & 24 & 27 \\
\hline $\begin{array}{l}\text { Mathematical competence and basic } \\
\text { competences in science and technology }\end{array}$ & 9 & 1 \\
\hline Digital competence & 3 & 16 \\
\hline Learning to learn & 14 & 6 \\
\hline Social and civic competences & 42 & 7 \\
\hline Sense of initiative and entrepreneurship & 6 & 32 \\
\hline Cultural awareness and expression & 2 & 6 \\
\hline
\end{tabular}

As can be seen from table 4 , for both grade levels, the social and civic $\left(4^{\text {th }}\right.$ grade $=42,5^{\text {th }}$ grade $=32)$ and communication in the mother tongue $(\mathrm{f}=24 / 27)$ competences were common in the curriculum. In regard to the other competences, the numbers of objectives were found to be $14 / 7$ for learning to learn, $6 / 6$ for sense of initiative and entrepreneurship, 9/16 for mathematical competence and basic competences in science and technology, 2/5 for cultural awareness and expression and $3 / 6$ for digital competences. The communication in foreign languages competence is included only at the $5^{\text {th }}$-grade level and is expressed as a objective under one item as "become aware of some of the cultures, lifestyles and languages of some countries in the European Union and the wider world (Ireland Primary School Curriculum, 1999) encompassing also the cultural awareness and expression competence.

\section{Conclusion, Discussion and Recommendations}

Lifelong learning is one of the priority approaches taken into consideration in education curricula, together with approaches to address the changes in the world and in education. Implementing a curriculum that has been developed according to education processes using this approach is of importance in ensuring the attainment of lifelong learning skills and learning habits from which individuals can draw upon throughout their lives. This study makes a comparative analysis of the Turkish and Irish curricula related to social studies, with particular emphasis on the key competences identified by the European Commission. 
Koç, E. S., \& Erdem, A. (2016). A comparative analysis of handling level of lifelong learning competences in social education curricula, Turkey and Ireland sample. International Journal of Human Sciences, 13(1), 1293-1303. doi:10.14687/ijhs.v13i1.3618

The findings of this study reveal that the skills taught were connected mainly to mathematical competence and basic competences in science and technology, as well as communication in the mother tongue competence in the TSSC. Competences such as communication in foreign languages and cultural awareness and expression were undertaken as appropriate. Similarly; in regards to the distribution of a total of 92 attainments of the 4th- and 5thgrade curricula, it was observed that the most frequent competence undertaken was mathematical competence and basic competences in science and technology $(\mathrm{f}=30)$, accounting for almost one third of the attainments. No common attainments were found at either grade level in digital competence or in the communication in foreign languages competence; furthermore, the number of attainments related to communication in the mother tongue (8) and sense of initiative and entrepreneurship (5) were seen to be few.

When skills and attainments in the TSSC were analysed together, it was found that the most frequent competences were mathematical competence and basic competences in science and technology. The most significant shortcoming of the curriculum in regard to the lifelong learning competence was that it did not include any competence or related skills under the competence of communication in foreign languages. Although the key competences identified by the European Commission were included in the curriculum to a large degree, it can still be said that the TSSC does not sufficiently reflect the key competences when the distribution of attainments to competences are considered. In a study by Demirel (2011) of lifelong learning skills in the primary education curriculum, a similar finding was reached. Demirel found that although lifelong learning features and skills are focused on more today than in the curriculum of the past, the number of attainments indicating lifelong learning is not sufficient.

The first element to be examined within the scope of the ISSC was the history curriculum. In this regard, it was found that the objectives and broad objectives were connected mainly to social and civic competences and learning to learn competences. A review of quantitative data related to the addressed skills and objectives according to grade level showed that the communication in mother tongue and learning to learn competences were at the forefront. In regard to the objectives and broad objectives of the geography curriculum, the learning to learn competence and mathematical competence, as well as basic competences in science and technology, were mainly taken into consideration, and emphasis tended to be on the cultural awareness and expression competence in skills, when presented according to grade level. It was observed that the objectives connected to mathematical competence and basic competences in science and technology were mainly taken into consideration when examined in accordance with the objectives for the grade levels.

The objectives and broad objectives of the SPHE curriculum were connected with the social and civic competence, the sense of initiative and entrepreneurship competence, cultural awareness and expression, and the mathematical competence and basic competences in science. As is in the case of other curriculums, in this program skills were also not outlined and social and civic competences and communication in the mother tongue were emphasized mostly by means of goals. In a holistic evaluation of the curricula in the scope of social studies is conducted, it was interesting to find that each curriculum places emphasis on a different competence. In this light, it can be stated that the competences of communication in the mother tongue, social and civic competences, the learning to learn competence, and mathematical competence and basic competences in science are of leading importance. Although all of the key competences are considered in the curriculum, it is seen that the competences of sense of initiative and entrepreneurship, cultural awareness and expression, communication in foreign languages, and especially digital competence, are not sufficiently reflected.

According to the findings of this study, the ISSC considers all key competences identified by the European Commission. The most prominent difference between the ISSC and TSSC is that the TSSC does not sufficiently include the communication in foreign languages competence. 
Koç, E. S., \& Erdem, A. (2016). A comparative analysis of handling level of lifelong learning competences in social education curricula, Turkey and Ireland sample. International Journal of Human Sciences, 13(1), 1293-1303. doi:10.14687/ijhs.v13i1.3618

Furthermore, it can be said that although both curricula include the social and civil competence, the international perspective of the issue is better reflected in the ISSC. It is suggested that the TSSC should be developed by taking into consideration this competence to ensure that it is better equipped. It is considered that TSSC is going to be better equipped if it is developed by taking these qualifications into account. Stating that the lowest participation rates to lifelong learning is in Turkey, in their study, where they compared the participation rate to lifelong learning in Turkey with European countries, Poyrak and Titrek (2013) remarked the obstacles, before our country to develop the view of lifelong learning in our country, must be overcome. In this respect, it is thought that one of these obstacles can be solved by means of revising the existing curriculum. In addition, as there are key competences, determined to be insufficient in the curriculum of both countries, it is suggested that the curricula should be developed by being revised in respect to the determined deficiencies, so as to have the programs achieved the qualification, which is convenient for lifelong learning model.

\section{References}

Aykaç, N. (2007) The Teacher' opininons about the elemantary social science lesson. Electronic Journal of Social Sciences.http://www.e-sosder.org. 6, (22), 46-73.

Aspin N.D, Chapman J.D 2000. Lifelong learning: concepts and conception. İnternational Journal of Lifelong Education. 19(1):2-19.

Bagnall R.G 2006. Lifelong learning and the limits of tolerance. International Journal of Lifelong Education. 25 (3): 257-269.

Beycioğlu K, Konan N 2008. Lifelong learning and European educational policies. Electronic Journal of Social Sciences. 7 (24):369-382.

Budak Y 2009. Lifelong learning and human type that should be aimed at the primary school curriculums. Gazi University Journal of Education Faculty. 29(3):693-708.

Coşkun Y.D, Demirel M 2012. Lifelong learning tendencies of university students. H.U. Journal of Education. 42:108-120.

Demirel M 2011. Lifelong learning and its reflections on Turkish Elementary Education Curricula. International Journal of Curriculum and Instructional Studies. 1(1):87-105.

Ersoy A. Lifelong learning and public libraries in Turkey. Master's Thesis. Ankara. 2009.

European Commission 2006. Official Journal of the European Union on 30 December 2006/L394.Retrieved 16 June 2015, from (http://eurlex.europa.eu/LexUriServ/site/en/

oj/2006/1_394/1_39420061230en00100018.pdf)

Gencel İ.E 2013. Prospective teachers' perceptions towards lifelong learning competencies. Education and Scince. 38 (170):237-252.

Göksan T.S, Uzundurukan S, KESKIN N.S 2009. Lifelong learning and lifelong learning programs of EU. 1st Constructional Engineering Symposium, Antalya, 6-7 December 2009.

Gökçe O (2006). Content Analysis - Theoretical and Practical Knowledge, Ankara: Siyasal Bookstore.

Ireland Primary School Curriculum (1999), Goverment of Ireland. Retrieved 12 July 2015 fromhttp://www.ncca.ie/en/Curriculum_and_Assessment/Early_Childhood_and_Primar y_Education/Primary-Education/Primary_School_Curriculum/ 
Koç, E. S., \& Erdem, A. (2016). A comparative analysis of handling level of lifelong learning competences in social education curricula, Turkey and Ireland sample. International Journal of Human Sciences, 13(1), 1293-1303. doi:10.14687/ijhs.v13i1.3618

Karakuş C 2013. Lifelong learning competences of vocational school students. Journal of Research in Education and Teaching. 2(3):26-35.

MEB (2006). Social Studies National Currciulum of Turkey. Ankara National Ministry of Education.

MEB (2009). Turkey Lifelong Learning Strategy Document, High Commission of Planning. Ankara, National Ministry of Education.

Poyraz, H., \& Titrek, O. (2013). Development of lifelong learning in Turkey.. Abant İzzet Baysal University Journal of Education.13(1).

Sağlam, M., Özüdoğru, F. ve Çıray, F. (2011). The European Union education policies and their effects upon Turkish Education System. . Yüzüncü Yıl University Journal of Education Faculty. 8 (1), 7-109.

Selvi K 2011. Teachers' lifelong learning competencies. International Journal of Instructional Studies. 1(1): 61-69.

Soran H, Akkoyunlu B, Kavak Y 2006. Lifelong learning skills and training faculty members: a project at Hacettepe University. H.U Journal of Education.30,201-210.

Uzunboylu H, Hürsen Ç 2011. Lifelong learning competence scale:the study of validity and reliability. H.U Jouranl of Education. 41:449-460.

Yıldırım A, Şimşek H 2008. Qualitative research methods in the social sciences. Ankara: Seçkin Publishing. 